\title{
Microstructure and Properties of High Chromium White Cast Irons Alloyed with Boron
}

\author{
Julieta Kaleicheva \\ Faculty of Industrial Technology \\ Technical University of Sofia \\ Sofia, Bulgaria \\ jkaleich@tu-sofia.bg \\ Zdravka Karaguiozova \\ Space Research and Technology \\ Institute \\ Bulgarian Academy of Sciences \\ Sofia, Bulgaria \\ karazuzi@yahoo.com
}

\author{
Krasimir Kirov \\ Arsenal J.S.Co. \\ Kazanlak, Bulgaria \\ kirov_krasimir_1966@abv.bg
}

\author{
Valentin Mishev \\ Faculty of Industrial Technology \\ Technical University of Sofia \\ Sofia, Bulgaria \\ v_mishev@tu-sofia.bg
}

\begin{abstract}
The microstructure and mechanical properties of high chromium white cast iron with composition: $2,6 \div 3,4 \% \mathrm{C} ; 0,9 \div 1,1 \% \mathrm{Si} ; 0,8 \div 1,1 \% \mathrm{Mn} ; 1,0 \div 1,3 \% \mathrm{Mo}$; $12,3 \div 13,4 \% \mathrm{Cr}$, additionally doped with boron in an amount of $0,18 \%$ to $1,25 \%$ is investigated. The microstructure of six compositions of white cast irons is studied by means of an optical metallographic analysis - one without boron, and the others contain $0,18 \% ; 0,23 \% ; 0,59 \% ; 0,96 \%$ and $1,25 \%$ boron.
\end{abstract}

A test is performed to determine: hardness by the Rockwell method; microhardness; bending strength and impact toughness. It was found that at a boron content of $0,18 \% ; 0,23 \%$ and $0,59 \%$, the structure of white cast irons is subeutectic, with impact toughness in the range of $1,80 \div 1,52$ $\mathrm{J} / \mathrm{cm} 2$; with a boron content of $0,96 \%$, the structure of white cast iron is close to the eutectic, with impact toughness 0,98 $\mathrm{J} / \mathrm{cm} 2$; at a boron content of $1,25 \%$ the structure of white cast iron is supereutectic and the impact toughness decreases to $0,68 \mathrm{~J} / \mathrm{cm} 2$.

With a change in the boron content from $0,8 \%$ to $1,25 \%$, the amount of carbide phase in the structure of white cast iron increases, which leads to an increase in hardness from 53 to 59 HRC. The highest bending strength $(\mathrm{Rmi}=660,85$ MPa) was obtained in white cast irons with a boron content of $0,23 \%$.

Keywords - high chromium white cast iron, boron, microhardness, hardness, impact toughness, bending strength

\section{INTRODUCTION}

High chromium white cast iron is white cast iron with high chromium content between $11 \%$ and $30 \%$ and carbon between 1,8-3,6\%. The presence of high chromium content in the white cast iron volume leads to the replacement of some parts of iron carbide with chromium one. The hardness and the toughness of which is higher than iron carbide in unalloyed white cast iron. The proportional dependence is observed between the carbon and chromium content increase and improvement in the hardness and wear resistance of white cast iron [1, 3, 4, 8]. In the highchromium irons, as with most abrasion-resistant materials, there is a trade-off between wear resistance and toughness. It is found that the abrasive wear resistance of high chromium cast iron (HCCI) alloys rely on their chemical composition and microstructure [4, 8]. By varying composition and heat treatment, these properties can be adjusted to meet the needs of most abrasive applications $[3,7]$.

High chromium white cast irons have not only excellent wear but in addition a good corrosion resistance results primarily from the presence of high-volume fraction of very hard eutectic carbides in a strong supporting matrix in their microstructure. Due to inexpensiveness of the high-Cr white cast irons they are used for production impact coal crusher hammers, pulveriser rings, chute liner, and hard facing alloys of rolls or molds [4]. These properties of white cast iron could be improved by adding some elements mostly elements forming strong carbides as molybdenum, vanadium, boron [9-11]. In [1] authors find the formation $\mathrm{Mo}_{2} \mathrm{C}$ by molybdenum addition less than $2 \%$. This could not improve its hardness in as-cast condition, but the vanadium and boron addition improve the hardness 
of high chromium white cast iron significantly [8]. The influence of both elements is different. Vanadium dissolves into the austenitic matrix and carbide $\mathrm{M}_{7} \mathrm{C}_{3}$, while boron generates finer structure of eutectic carbide, needle like structure (upper bainite) matrix, and martensite on carbide boundary [1]. In high boron white cast iron with 4 wt\% chromium modificated with rare earth magnesium alloy the primary austenite and the eutectic borides are refined. After High temperature heat treatment of this alloy granulation of the borides and the improvement of toughness and tensile strength are observed [2]. Investigation of the destabilization heat treatments undertaken at temperatures of 825,900 and $975^{\circ} \mathrm{C}$ for 25 minutes shows for the iron containing boron, a density of carbide particles per square micron at $825^{\circ} \mathrm{C}$, is more than this one achieved at $975^{\circ} \mathrm{C}$. In the case of the alloy without boron additions, the same relation is defined, but the quantity of the carbides is significantly less. Higher volumes of carbide precipitation imply higher values of bulk hardness and microhardness in the alloys. The results suggest that boron works as nuclei for the precipitation of secondary carbides [5]. A similar effect of hardness and wear improvement is determined due to additions of titanium of $1 \%, 3 \%$ and $5 \%$ to a $12 \% \mathrm{Cr}-$ $3 \% \mathrm{C}$ white iron. Some part of carbon is consumed to form primary $\mathrm{TiC}$ during solidification and a decrease in the carbon content in the alloy occurs. The results are decrease in the eutectic $\mathrm{M}_{7} \mathrm{C}_{3}$ carbide volume fraction and promotion a more martensitic matrix. The best combination of austenite/martensite matrix reinforced with primary $\mathrm{TiC}$ carbides was obtained at $3 \%$ amount of titanium results in best wear behavior, whereas bulk hardness increases proportionally with the increase in the amount of titanium. Heat treatment leads to the precipitation of secondary carbides occurred within the matrix, which improved the wear resistance of most irons. The best behavior is observed again at 3\%Ti iron, which is caused by obtained microstructure; particularly in the well distribution of primary TiC carbides within the matrix [6]. Significant impact of the heat treatment process on the Microstructural Characteristics and Mechanical Properties High-Cr White Cast Iron Alloys is manifested in the work [7]. The work shows an essential role of the temperature increase during heat treatment on the change of the microstructure and therefore on the improvement of the wear resistance through microstructure refinement and in situ formation of fine new carbides. The carbide morphology also influences on the wear and fracture behavior of high chromium white irons. The increase of the carbide volume fraction for the austenitic and martensitic structures is a reason for the hardness increase. The austenite content influence on the abrasion resistance at least to $20-30 \%$ level. The quantity above this level of austenite content abrasion resistance is independent. Destabilization heat treatment for high-Cr white cast irons is employed to obtain the martensitic structure for improving the toughness and abrasion resistance of these cast irons [7]. The presence of the carbide forming elements in high carbon cast irons play a significant role in their influence on the wear resistance. Chemical composition of these irons' forms different proportion content between $\mathrm{M}_{7} \mathrm{C}_{3}, \mathrm{M}_{3} \mathrm{C}$ and $\mathrm{M}_{23} \mathrm{C}_{6}$ which determines their different morphology and hence different exploitation properties. Authors in [8] investigate effect of boron on the structure and properties of $13 \mathrm{Cr}-2,3 \mathrm{C}$ Chromium white irons. Increase in the boron content above $0,39 \%$ leads to higher tendency of boron-carbide formation. The prevalence of $\mathrm{M}_{7} \mathrm{C}_{3}$ carbides and a small quantity of $\mathrm{M}_{3} \mathrm{C}$ carbides is observed in the structure of the basic Fe-Cr-C alloy. Increase of the boron content increases the amount of $\mathrm{M}_{3} \mathrm{C}$ carbide, while the volume fraction of the $\mathrm{M}_{7} \mathrm{C}_{7}$ carbides remains unchanged. In the highest boron content about 0,59 wt\% secondary M23C6 carbides appear in the structure. The assumption of the formation of complex compounds of the type $\mathrm{M}_{3}(\mathrm{C}, \mathrm{B})$ and $\mathrm{M}_{23}(\mathrm{C}, \mathrm{B})_{6}$ is suggested [8].

The alloying of ductile cast irons with boron from 0,03 to $0,135 \%$ leads to formation of eutectic carbides from 9 to $27 \%$ in the iron structure. On the base of this irons new composition of carbide austempered ductile irons (CADI) with structure of lower and upper bainite are produced. These cast irons possess up to 3 times higher wear resistance during abrasive wear compared to this one without boron. In the structure of which there are no eutectic carbides (ADI) [12].

High chromium white cast irons are increasingly used in the practice as a wear-resistant and corrosion-resistant material. The additional alloying of these cast irons affects the chemical composition and dispersion of the carbide phase and the structure of the metal base after casting and heat treatment.

The aim of the present study is to investigate the microstructure, mechanical properties and wear resistance during abrasive wear of high chromium white irons, alloying with boron.

\section{MATERIALS AND METHODS}

The samples from high chromium white cast irons alloying with boron from $0,18 \%$ to $1,25 \%$ are investigated (table 1). These samples are made of test specimens sized $\varnothing 30$ x $340 \mathrm{~mm}$, cast in sand molds.

The microstructure of six compositions of white cast irons is studied by means of an optical metallographic analysis - one without boron, and the others contain 0,18\%; $0,23 \% ; 0,59 \% ; \quad 0,96 \%$ and $1,25 \%$ boron. The microstructural analysis is performed by means of an optical metallographic microscope NEOPHOT 32. The test samples are processed in the reagent composition: $20 \mathrm{~g}$ CuSO4, 100ml HCI, 100ml $\mathrm{C}_{2} \mathrm{H}_{5} \mathrm{OH}$.

A test is performed to determine hardness of the studied white cast irons by the Rockwell method (HRC). The microhardness $\mathrm{HV}_{0,1}$ of the metal matrix and the carbide phase in the structure of cast irons with loading $100 \mathrm{~g}$ is defined.

The impact toughness KC is performed by Charpy impact test. The tested samples used are sized 10x10x55 mm without notch. 
Environment. Technology. Resources. Rezekne, Latvia Proceedings of the $13^{\text {th }}$ International Scientific and Practical Conference. Volume 3, 137-141

The bending strength is carried out. The patterns are tested on the universal test machine with a bending device. The bending strength is determined by the formula:

$$
\left(\pi . d_{c}^{3}\right) \quad R_{m i}=81 . F_{\max } /
$$

where $\mathrm{F}_{\max }$ is a maximum load, $\mathrm{N}$; $\mathrm{d}_{\mathrm{c}}$ is an average diameter of the test body in the load place, $\mathrm{mm}$.

The wear resistance during abrasive wear is investigated as measured loss of mass in terms of dry friction under load of $1,5 \mathrm{~kg}$ during $10 \mathrm{~min}$. The tested sample sized $ø 30 \times 40 \mathrm{~mm}$ circles with speed $\mathrm{n}=150 \mathrm{~min}^{-1}$, pressed on an abrasive disc 99BA60R7V sized $250 \times 20 \times 20$ $\mathrm{mm}$.

TABLE 1 CHEMICAL COMPOSITION OF HIGH CHROMIUM WHITE CAST IRON ALLOYED WITH BORON

\begin{tabular}{|c|c|c|c|c|c|c|}
\hline \multirow{2}{*}{$\begin{array}{c}\text { Sample } \\
\text { № }\end{array}$} & \multicolumn{7}{|c|}{ Chemical element, \% } \\
\cline { 2 - 7 } & $\boldsymbol{C}$ & $\mathbf{S i}$ & $\mathbf{M n}$ & $\mathbf{M o}$ & $\boldsymbol{C r}$ & $\boldsymbol{B}$ \\
\hline $\boldsymbol{I}$ & 3,23 & 0,88 & 1,07 & 1,08 & 13,406 & - \\
\hline $\boldsymbol{I I}$ & 2,58 & 1,01 & 1,06 & 1,28 & 13,501 & 0,18 \\
\hline $\boldsymbol{I I I}$ & 3,22 & 1,11 & 1,06 & 1,27 & 13,351 & 0,23 \\
\hline IV & 2,77 & 1,00 & 0,93 & 1,05 & 13,175 & 0,59 \\
\hline V & 3,35 & 0,91 & 0,85 & 1,01 & 12,698 & 0,96 \\
\hline VI & 3,23 & 1,08 & 0,89 & 0,98 & 12,316 & 1,25 \\
\hline \multicolumn{7}{|c|}{ RESULTS AND DISCUSSION } \\
\hline
\end{tabular}

Fig. 1 show the microstructure of high chromium white cast irons composition presented in table 1 . The structure of the cast iron without boron is subeutectic (fig. 1a). Alloyed cast irons with 0,18\%; 0,23\%; 0,59\% boron possess also subeutectic structure, but boron presence in the mentioned content decreases the grain size of the primary austenite and is a reason for the formation of a more dispersed structure (fig. b, c, d). The more quantity of boron in these cast irons persist the increasing part of the carbide eutectic is observed in their structure. At 0,59\% boron (fig. 1d) the cast irons structure still is subeutectic, but it contains a large quantity of carbide eutectic. At boron content more than $0,6 \%$ to $1 \%$ the cast irons structure is approaching the eutectic. The microstructure of high chromium white cast iron with $0,96 \%$ boron is presented in fig. 1e. Besides carbide eutectic a certain amount of primary carbides is observed in this microstructure. At 1,25 \% boron content super eutectic structure of the cast irons is noted with rude primary carbides up to $70 \mu \mathrm{m}$ size (fig. 1f).

The increased percentage of the boron content in the tested cast irons structure leads to the quantity of the carbide phase increase (the volume of the carbide eutectic increases and in the cast irons with 0,96 and 1,25\% boron primary carbides are formed). This explain hardness increase from 53,5 HRC at $0,18 \%$ boron to $57,5 \mathrm{HRC}$ at $1,25 \%$ boron (table 2 ).
The influence of the boron content on the impact toughness of the tested cast irons is shown in fig. 2 and tabl.2. For the cast irons without boron and for those with 0,18 and $0,23 \%$ boron the rates of the impact toughness are close and are in the range from 1,88 to $1,72 \mathrm{~J} / \mathrm{cm}^{2}$. The increased percentage of the boron content is a reason of the quantity increase of the carbide phase in the cast irons structure and results in the impact toughness decrease from $1,52 \mathrm{~J} / \mathrm{cm}^{2}$ at $0,59 \%$ boron to $0,68 \mathrm{~J} / \mathrm{cm}^{2}$ at $1,25 \%$ boron.
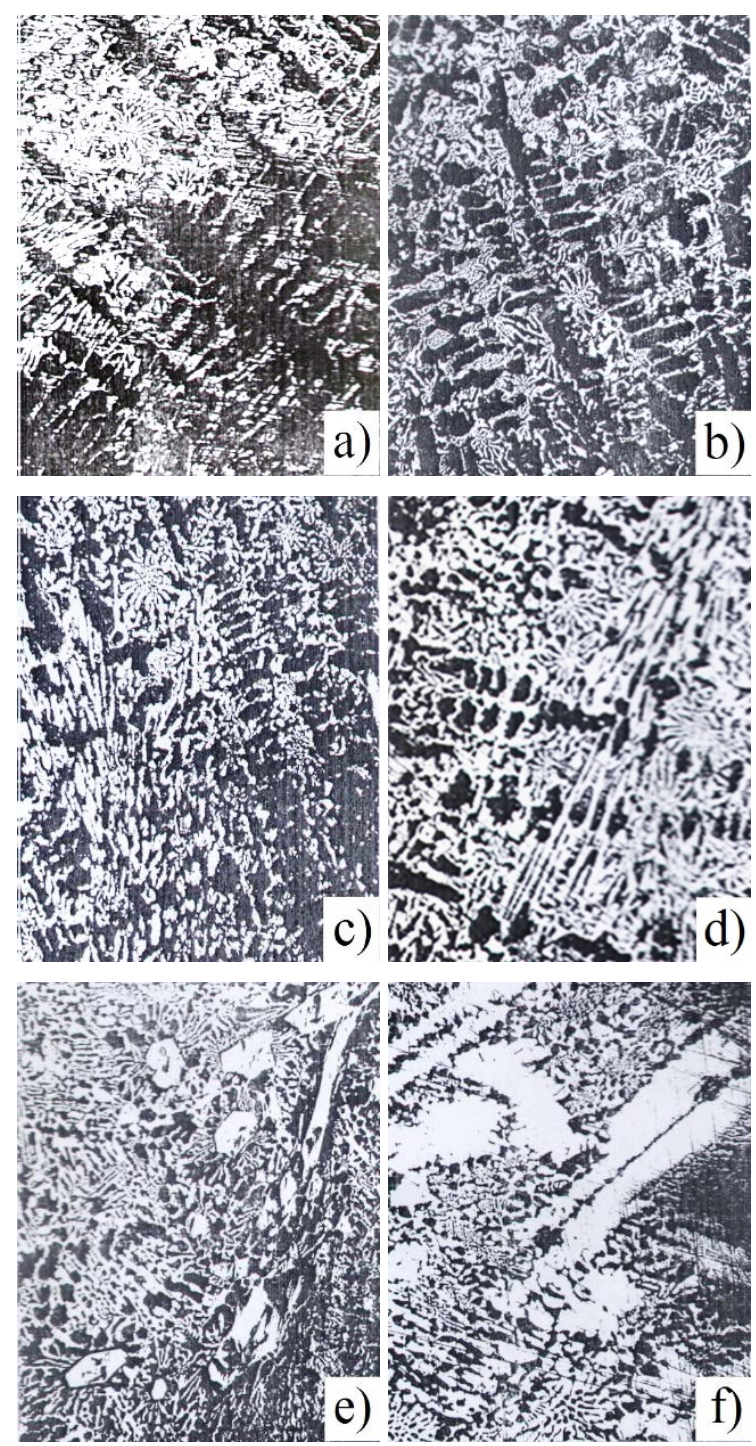

Fig.1. Microstructure of high chromium white cast irons alloyed with boron $\mathrm{x} 100$. a) - $0 \% \mathrm{~B}$; b) - 0,18\% B; c) - 0,23\% B; d) $-0,59 \% \mathrm{~B}$; e) - $0,96 \% \mathrm{~B}$; f) - $1,25 \% \mathrm{~B}$

TABLE 2 BENDING STRENGTH $R_{M I}$, IMPACT TOUGHNESS $K C$ AND HARDNESS HRC OF HIGH CHROMIUM WHITE CAST IRON ALLOYED WITH BORON 


\begin{tabular}{|c|c|c|c|c|}
\hline Sample № & $\begin{array}{c}\mathbf{B}, \\
\mathbf{\%}\end{array}$ & HRC & $\begin{array}{c}\mathbf{K C}, \\
\mathbf{J} / \mathbf{c m}^{2}\end{array}$ & $\begin{array}{c}\mathbf{R}_{\mathrm{mi}}, \\
\mathbf{M P a}\end{array}$ \\
\hline $\boldsymbol{I}$ & - & - & 1,88 & 536,80 \\
\hline $\boldsymbol{I I}$ & 0,18 & 53,5 & 1,80 & 531,20 \\
\hline III & 0,23 & 54,0 & 1,72 & 660,85 \\
\hline $\boldsymbol{I V}$ & 0,59 & 56,5 & 1,52 & 391,43 \\
\hline $\boldsymbol{V}$ & 0,96 & 57,0 & 0,98 & 374,74 \\
\hline VI & 1,25 & 57,5 & 0,68 & 293,27 \\
\hline
\end{tabular}

cast irons of $1749 \div 1854 \mathrm{HV}_{0,1}$ (fig. 5) is achieved at $0,96 \%$ boron. The dissolving of the boron in the austenite probably increases its resistance to transformation during cooling. The metal base structure at a room temperature could consists as ferrite-carbide mixtures (perlite, sorbite, troostite) as well as nonequilibrium structures (bainite, martensite) and retained austenite. The lowest microhardness is determined for the metal base in the cast irons without boron and the highest - in the cast iron with 0,96\% boron (825 $\left.\mathrm{HV}_{0,1}\right)$ (fig. 4).

TABLE 3. MiCROHARDNESS $H V_{0,1}$ OF THE METAL MATRIX AND CARBIDE PHASE OF HIGH CHROMIUM WHITE CAST IRON

From the performed bending test the bending strength $\mathrm{R}_{\mathrm{mi}}$ is defined for the tested high chromium white cast irons with a different boron content (fig.3, table 2). The highest bending strength is achieved for cast irons with $0,23 \%$ boron $\left(\mathrm{R}_{\mathrm{mi}}=660,85 \mathrm{MPa}\right)$.

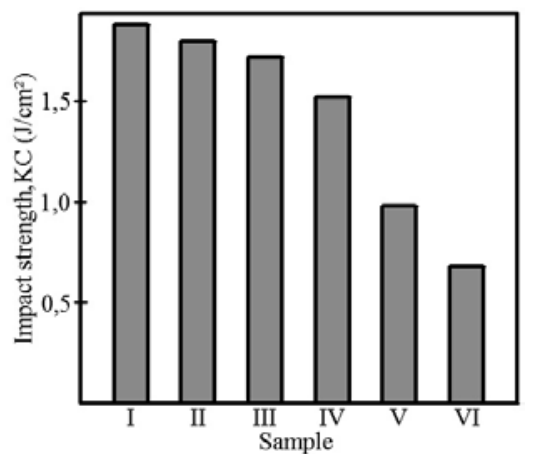

Fig.2. Dependence of the impact toughness $K C$ on the boron content in high chromium white cast iron

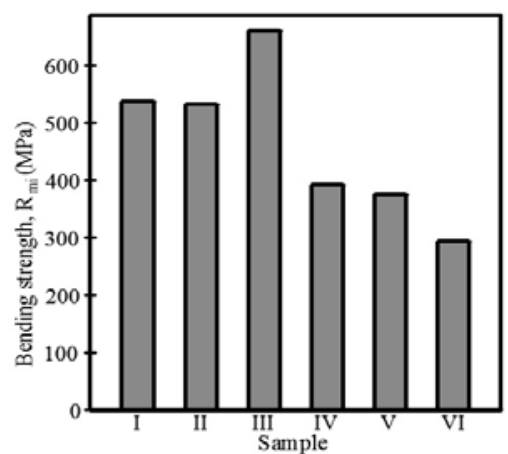

Fig.3. Dependence of the bending strength $R_{m i}$ on the boron content in high chromium white cast iron

The change of the microhardness $\mathrm{HV}_{0,1}$ of the metal base and of the carbide phase depending on the boron content in the studied cast irons is presented in fig.4, fig.5 and in table 3 . In the alloyed with chromium white cast irons depending on the percentage of the chromium content it is possible to observe the following carbide phase in the eutectic: $\mathrm{M}_{3} \mathrm{C}, \mathrm{M}_{7} \mathrm{C}_{3}$ or $\mathrm{M}_{23} \mathrm{C}_{6}$ [3]. In the irons with $13 \%$ chromium the eutectic carbide is $\mathrm{M}_{7} \mathrm{C}_{3}$. The addition of boron in the cast irons depending of its content this boron can alloy the carbide phases as well as to lead to the appearance of additional carbide phases [3,8]. The highest microhardness of the carbide phase in the boron alloyed ALLOYED WITH BORON

\begin{tabular}{|c|c|c|c|}
\hline Sample № & B, $\%$ & \multicolumn{2}{|c|}{$H V_{0,1}$} \\
\hline \multirow{3}{*}{$I$} & \multirow{3}{*}{ - } & metal matrix & 672 \\
\hline & & \multirow{2}{*}{ carbide phase } & 1427 \\
\hline & & & 1402 \\
\hline \multirow{3}{*}{ II } & \multirow{3}{*}{0,18} & metal matrix & 766 \\
\hline & & \multirow{2}{*}{ carbide phase } & 1097 \\
\hline & & & 1288 \\
\hline \multirow{3}{*}{ III } & \multirow{3}{*}{0,23} & metal matrix & 776 \\
\hline & & \multirow{2}{*}{ carbide phase } & 1354 \\
\hline & & & 1226 \\
\hline \multirow{3}{*}{ IV } & \multirow{3}{*}{0,59} & metal matrix & 786 \\
\hline & & \multirow{2}{*}{ carbide phase } & 1533 \\
\hline & & & 1226 \\
\hline \multirow{3}{*}{$V$} & \multirow{3}{*}{0,96} & metal matrix & 825 \\
\hline & & \multirow{2}{*}{ carbide phase } & 1854 \\
\hline & & & 1749 \\
\hline \multirow{3}{*}{$V I$} & \multirow{3}{*}{1,25} & metal matrix & 766 \\
\hline & & \multirow{2}{*}{ carbide phase } & 1402 \\
\hline & & & 1783 \\
\hline
\end{tabular}

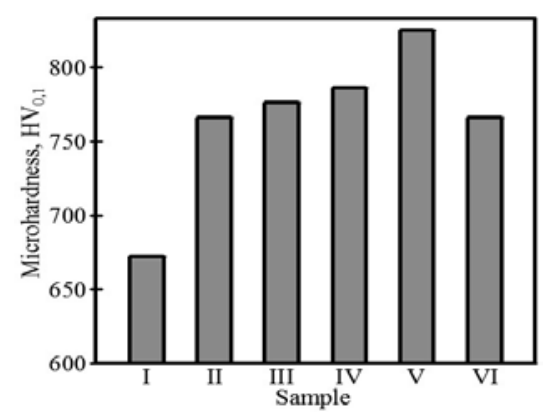

Fig.4. Dependence of the microhardness $H V_{0,1}$ of the metal matrix on the boron content in high chromium white cast iron

The lowest mass loss during abrasive wear test in dry conditions friction is defined for irons alloyed with $0,18 \%$ 
boron. The alloyed cast irons with 0,$18 ; 0,23$ and $0,59 \%$ boron, show higher wear resistance than this one without boron. The highest mass loss is determined during abrasive testing of alloyed cast irons with 0,96 and $1,25 \%$ boron (fig. 6, table 4).

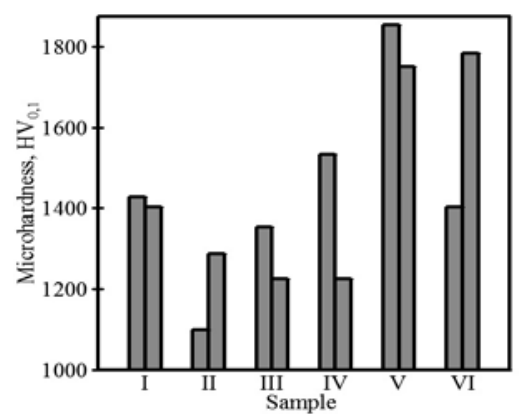

Fig.5. Dependence of the microhardness $H V_{0,1}$ of the carbide phase on the boron content in high chromium white cast iron

TABLE 4. TEST OF WEAR OF HIGH CHROMIUM CAST IRON ALLOYED WITH BORON

\begin{tabular}{|c|c|c|c|c|}
\hline Sample № & $\mathbf{B , ~} \%$ & $\mathbf{m}_{\mathbf{0}}, \mathbf{g}$ & $\mathbf{m}, \mathbf{g}$ & $\Delta \mathbf{~ m , g}$ \\
\hline $\boldsymbol{I}$ & - & 142,5032 & 142,2341 & 0,2691 \\
\hline II & 0,18 & 147,4415 & 147,2946 & 0,1469 \\
\hline III & 0,23 & 145,9076 & 145,7297 & 0,1779 \\
\hline IV & 0,59 & 143,6850 & 143,4546 & 0,2304 \\
\hline V & 0,96 & 143,8705 & 143,5771 & 0,2934 \\
\hline VI & 1,25 & 147,6045 & 147,2214 & 0,3831 \\
\hline
\end{tabular}

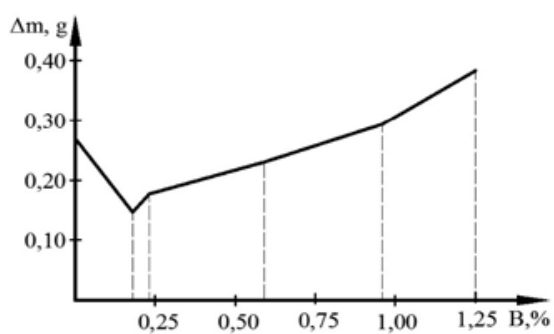

Fig.6. Amendment of the weight loss $\Delta \mathrm{m}$ during abrasive wear test depending on the boron content in high chromium white cast iron

\section{CONCLUSIONS}

Additional alloying with boron of the high chromium white cast iron $13,1 \mathrm{Cr}-3,1 \mathrm{C}-1,1 \mathrm{Mo}$ change the microstructure of the cast iron. The microstructure of the cast irons without boron and with $0,18 \% ; 0,23 \%$ and $0,59 \%$ boron is subeutectic, with $0,96 \%$ boron - is close to the eutectic and with $1,25 \%$ boron - supereutectic. Boron alloying decreases grain size of the primary austenite in the subeutectic structure of the cast irons and increases carbide eutectic dispersion. The highest irons impact toughness is achieved in the cast irons without boron and in these of them with $0,18 \%$ and $0,23 \%$ boron ( $\mathrm{KC}$ is from 1,88 to 1,72 $\mathrm{J} / \mathrm{cm}^{2}$ ). The bending strength is highest in the alloyed irons with $0,23 \%$ boron $\left(\mathrm{R}_{\mathrm{mi}}=660,85 \mathrm{MPa}\right)$. The alloyed cast irons with $0,18 \%, 0,23 \%$ and $0,59 \%$ boron have higher wear resistance compared to this one of the cast irons without boron.

\section{ACKNOWLEDGMENTS}

The authors would like to thank the Research and Development Sector at the Technical University of Sofia for the financial support.

\section{REFERENCES}

[1] F. Nurjaman, S. Sumardi, A. Shofi, M. Aryati, and B. Suharno, "Effect of molybdenum, vanadium, boron on mechanical properties of high chromium white cast iron in as-cast condition", AIP Conference Proceedings, vol.1711, №020005, February 2016. [Online]. Available: https://aip.scitation.org. [Accessed Sept. 28, 2020].

[2] Xiang Chen, Yanxiang Li and Huiming Zhang, "Microstructure and mechanical properties of high boron white cast iron with about 4 wt\% chromium", Journal of Materials Science, vol.46, p.957963, February 2016. [Online]. Available: https://www.researchgate.net. [Accessed Sept. 27, 2020].

[3] A. Nofal, "Metallurgical Aspects of High- Chromium White Irons", www.foundry-planet.com. [Online]. Available: https://www.foundry-planet.com/fileadmin/redakteur/pdfdateien/13-Adel-Nofal.pdf. [Accessed Sept. 27, 2020].

[4] Kh. Abd El-Aziz, Kh. Zohdy, D. Saber and H. E. M. Sallam, "Wear and Corrosion Behavior of High-Cr White Cast Iron Alloys in Different Corrosive Media”, Journal of Bio- and Tribo-Corrosion vol.1, №25, August 2015. [Online]. Available: https://link.springer.com. [Accessed Sept. 25, 2020].

[5] A. Bedolla-Jacuinde, F. V. Guerra, I. Mejía, J. Zuno-Silva and C. Maldonado,"Boron Effect on the Precipitation of Secondary Carbides During Destabilization of a High-Chromium White Iron”, International Journal of Cast Metals Research, vol.29, issue:1-2, p.55-61, February 2016.[Online].

Available: https://www.tandfonline.com. [Accessed Sept. 25, 2020].

[6] S. Reyna, A. Bedolla-Jacuinde, F.V. Guerra, I. Mejía and M. García, "Effect of amount and distribution of primary TiC on the wear behavior of a $12 \% \mathrm{Cr}-3 \% \mathrm{C}$ white iron under dry sliding conditions”, Wear, №203718, February 2021.[Online]. https://www.researchgate.net. [Accessed March. 10, 2021].

[7] Kh. Abdel-Aziz, M. El-Shennawy* and Adel A. Omar, "Microstructural Characteristics and Mechanical Properties of Heat Treated High-Cr White Cast Iron Alloys”, International Journal of Applied Engineering Research, vol.12, №14, p.4675-4686, January 2017. [Online].

https://www.researchgate.net. [Accessed March. 2, 2021].

[8] S. M. Tomovic-Petrovic, S. V. Markovic and S. Zec, "The effect of boron on the amount and type of carbides in chromium white irons", Journal of the Serbian Chemical Society, vol.67(10), p.697707, January 2002. [Online]. https://www.researchgate.net. [Accessed Sept.. 28, 2020].

[9] K. Ibrahim, " Investigation of improving wear performance of hypereutectic 15\% Cr-2\% Mo white irons", China Foundry, vol.7(4), p.438-446, November 2010. [Online]. https://www.researchgate.net. [Accessed Sept.. 29, 2020].

[10] C. Scandian, C. Boher, J.D.B de Mello and F. Rezai-Aria, "Effect of molybdenum and chromium contents in sliding wear of high-chromium white cast iron: The relationship between microstructure and wear”, Wear, vol.267, issues:1-4, p.401-408, May 2009.[Online]. https://www.sciencedirect.com. [Accessed Sept.. 29, 2020].

[11] J.D.B. de Mello, A. A. Polycarpou,"Abrasive wear mechanisms of multi-components ferrous alloys abraded by soft, fine abrasive particles”, Wear , vol.269, issues:11-12, p.911-920, October 2010. [Online]. https://www.sciencedirect.com. [Accessed Sept.. 29, 2020].

V.P.Todorov, "Influence of the carbide phase on the mechanical and operational characteristics of bainitic cast irons”, Ph.D. dissertation, Technical University - Gabrovo, Gabrovo, Bulgaria, 2016. 